\title{
Implementing business ethics in large British organisations
}

\author{
Russell Abratt \&Nicola Higgs \\ Graduate School of Business Administration, University of the Witwatersrand, P. 0. Box 98, WITS 2050, Republic of South Africa
}

\author{
Accepted November 1994
}

\begin{abstract}
Much attention has been paid to ethics in the realm of business where it is believed that a company should focus not only on the development of ethical business policies, but the implementation thereof as well. While ethical behaviour in business has been accepted, the implementation of ethical policies is proving to be difficult. In this article we firstly review the business ethics implementation literature with a particular focus on codes of conduct. We then present results from a study of British companies, commenting on methods of fostering ethical behaviour, the use of formal codes of ethics, management's involvement in implementation, and the effectiveness of codes of business practice. The results show that large British organisations are becoming more ethically aware, but still have some way to go in implementing ethical policies.
\end{abstract}

\begin{abstract}
Etiek binne die sake-omgewing geniet baie aandag. Daar word van maatskappye verwag om nie slegs 'n etiese sakebeleid daar te stel nie, maar ook om dit ook te implementeer. Alhoewel die beginsel van etiese sakepraktyke algemeen aanvaar word, is die implementering van 'n etiese sakebeleid dikwels moeilik. Hierdie artikel bestaan eerstens uit 'n oorsig van die literatuur on die implementering van sake-etiek, waarin riglyne vir optrede beklemtoon word. Tweedens word die resultate van ' $n$ ondersoek onder Britse Maatskappye uiteengesit. Die bespreking omvat maniere waarop etiese gedrag aangemoedig kan word, die gebruik van formele etiese riglyne, die betrokkendheid van bestuur by implementering en die doeltreffendheid van riglyne vir sake-etiek. Uit die resultate blyk dit dat groot Britse ondernemings toenemend bewus word van etiek maar dat die implementering van etiese sakebeleid steeds verbeter behoort te word.
\end{abstract}

\section{Introduction}

The issue of ethics in the realm of business where it is believed that a company should focus not only on the development of ethical business policies, but the implementation thereof as well, has received much attention. Literature on business ethics has grown in importance and in volume in recent years (Leory \& Caldwell, 1992; Purcell, 1977). The major issue facing companies in the future will be on how to implement ethical behaviour rather than just to accept its importance. It is imperative to have a thorough persuasive style of attention to and assessment of ethical concerns if there is to be a difference in behaviour throughout the entire organisation (Oliverio, 1989). The primary aim of this study is to investigate the stance adopted by business in its approach to ethics in Britain. More specifically the aim of this article is to establish how English companies implement ethics in their organisations, by the use of a code of business practice, or by some other means.

\section{Literature}

\section{Implementing business ethics}

The integration of ethics into the organisation's decisionmaking process is by no means a simple task. A review of the literature indicates that strategic, cultural, structural and leadership factors are all important considerations when attempting to implement and control ethical behaviour. Finlay (1989) notes that introducing and enforcing business ethics requires a cultural and strategic commitment on the part of the entire organisation directed at persuasively articulating, rigorously applying and vigorously enforcing ethical behaviour.

The implementation of business ethics begins with a strategic commitment. Andrews (1989) comments that once a company's leaders have decided to manage their performance and intentions, ethically they should determine their corporate policy and make it explicit. Schlegelmilch \& Houston (1989) remark on the shift away from the scepticism of the existence of a corporate conscience towards a greater acceptance on the part of management of the need to conceptualize and implement ethical behaviour. Brenner (1992) notes that organisations are often committed to ethical programmes, but that these are not explicitly created, and are inherent in the culture and process of the organisation. Whilst this may be so, many authors suggest that management should take explicit steps in implementing ethics programmes.

The development of an organisational culture, the systems of shared values, beliefs, attitudes, norms and mores of the organisational members, which is conducive to ethical behaviour, is recognized as being central to the objective of promoting ethical decision making (Gandz \& Bird, 1989). Epstein (1979) suggests that before managers can make decisions about resource allocations and priorities, they must determine the values, goals and culture of the firm and its constituencies. Knouse \& Giacalone (1992) propose that the use of organisational stories and rhetoric to develop culture is an important factor in providing ennployees with both organisationally sanctioned and/or unsanctioned methods of engaging in ethical decision making.

Murphy (1988) stresses the importance of creating not only the appropriate culture, but a structure that is directed at fostering ethical behaviour. Gandz \& Bird (1989) note that an ethical organisation can be shaped using the tools of organisational design, structure and systems, to build a broad base of people who are committed to moral management and ethical behaviour.

The role of top management is instrumental in the development and implementation of the ethical programme (Murphy, 1988; Olivero, 1989). Simply creating a strategy, structure and culture that promotes ethical decision making is not 
enough. Management must also communicate and enforce a well thought-out code of ethics (Weeks \& Nantel, 1992). Enderle (1987) cautions that managerial ethical leadership may not be enough, owing to the limitations on the decision and action space of the leader imposed by the corporation, the economy and other factors. This sentiment is also shared by Murphy, Smith \& Daley (1992), who propose that a leader's support of ethical behaviour is not sufficient to ensure such behaviour. They suggest that ethical conduct is more likely to occur when actively managed by someone with narrower or more focused activities.

An essential aspect of the implementation of ethical conduct is the communication of expectations to employees. Delaney \& Stockwell's (1992) survey illustrates that ethics training programmes have a positive influence in organisations because they expose individuals to difficult problems, encourage them to make decisions and convey a message that top management supports such ethical efforts.

Knouse \& Giacalone (1992) stress that taking the above steps is not the end of the implementation process. Management must not only inform, but they must control. Codes of ethics are often used as an important management tool in both informing and controlling employees. Authors such as Davis \& Walton (1991) and Purcell (1977) stress the importance of compiling codes of conduct in order to implement ethics successfully. Ethical organisations often expand the traditional sphere of external and internal audits to include compliance with ethical codes. The following section addresses the topic of codes of ethics.

\section{Codes of ethics}

Before examining empirical evidence relating to the use of codes of ethics in practice, it is important to define the concept of a code of ethics, and discuss arguments for and against the use of ethical codes. The defining of the term 'code of ethics' is no simple task given the many interpretations of this concept. According to Starr (1983), codes of ethics are to a large extent rules. Weller (1988) adds to this by proposing that codes are statements of rules, which guide present and future action and in this sense are sets of policies. Another view is held by Sims (1991) who comments that a code of ethics describes the general value system of the organisation's purpose and provides guidelines for decision making, consistent with these principles. Brooks (1989) and Buller et al. (1991) believe that corporate codes of ethics are the statements which outline how employees ought to act in certain situations. In addition, Byron \& Williams (1977) specify that a typical code will define the trusts that must not be violated, the secrecy that must be avoided, and the forms of easy money that will carry corruption into the company and into the system. Drawing these thoughts together, one could conclude that a corporate code of ethics is an established (usually written) collection of rules concerned with what is right and wrong in a particular business.

Codes of ethics have been justified as being a valuable tool for improving the ethical atmosphere of the business (Arrow, 1973; Starr, 1983). A more structured form of communication needs to be employed due to the fact that leaders are unable to communicate ethical behaviour continuously and directly with those below them, therefore an ethical code is necessary
(Molander, 1987). Researchers have stated that a code of ethics can be seen as the principle means of guiding employees to behave ethically (Brenner \& Molander, 1977; Brooks, 1989; Murphy, 1988; Schlegelmilch \& Houston, 1989; Tsalikis \& Fritzsche, 1989). Raiborn \& Payne (1990) believe that one of the major benefits of introducing a code is the process of discovering and harmonizing managers' interest, in an attempt to establish a code of ethics.

In spite of the fact that codes have been justified, the literature identifies a number of limitations in practice. Cressey \& Moore (1983), as well as Benson (1989), feel that the corporate organisation, despite ethical preaching, discourages ethical behaviour as the pressures to perform are so intense and goals so unreasonable, that middle managers believe the only way out is to bend the rules, even if it means compromising personal ethics. Cressey \& Moore (1983) and Chatov (1980) further criticize corporate codes because of the wide variety of their concerns. In addition, research conducted by Murphy, Smith \& Daley (1992), found a weak relationship between the existence of ethical codes and ethical behaviour.

Molander (1987) notes the limitations of codes of ethics. He comments that an ethic of moral principles regulating society's interdependent relationships should be developed. Brenner \& Molander (1977) found that the respondents believed that a code of ethics is limited in its ability to change human conduct. According to a survey by Donaldson (1989), respondents said that codes were irrelevant to business because they miss the main point of business - maximizing profits. It has also been stated that clauses in codes of ethics become counter-productive if the language used is vague (Starr, 1983). Codes may fail to indicate how far an executive should go in risking other peoples' money (Benson, 1989). Furthermore, a code can tell a corporation to be a good citizen in his community but it would be difficult to prescribe the community which should be selected by the business.

Both Molander (1987) and Benson (1989) stipulate that some of the limitations of codes of ethics may be overcome by designing adequately composed and carefully administered codes of ethics. A number of scholars and researchers have stated that an effective code must be well written, usable and viable and have given some suggestions on how to develop one (Benson, 1989; Murphy, 1988; Molander, 1987; Raiborn \& Payne, 1990). In other words, in order for business ethics to be effectively implemented, formal, well-written codes of conduct should be compiled.

Empirical research addressing the topic of codes of ethics has been conducted fairly widely in the United States of America (Brenner \& Molander, 1977; Becker \& Fritzche, 1987; Laczniak \& Interrieden, 1987; the Centre for Business Ethics, 1986). Altogether $90 \%$ of large American companies have codes of ethics as do $75 \%$ of large Canadian companies (Lefebvra \& Singh, 1992).

In contrast to the United States, there is a dearth of English literature on business ethics in general and corporate codes of ethics in particular (Schlegelmilch \& Houston, 1989). In 1976, Melrose-Woodman and Kverndal investigated the development and motivation behind codes of ethics in UK companies possessing a code of ethics. Research by Schlegelmilch \& Houston (1989) into the largest 200 companies 
in Britain reveals that only $31 \%$ have introduced codes of conduct.

\section{Mothod}

The objective of this study was to collect data on how large British companies implement business ethics in their organisations. A mail survey was undertaken which involved sending out a semi-structured questionnaire and covering letter to the Chief Executive Officer of 300 British companies listed in the Times 1000, 1991/92 (1992).

\section{Instrument}

The questionnaire comprised three sections. The first section asked respondents whether or not their company has implemented a code of ethics or any other mechanism which fosters ethical decision making. The second section attempted to determine different aspects concerning the companies' codes of ethics and the third section concerns companies that do not have specific codes of ethics. The questionnaire mainly contained closed-ended questions, but a number of open-ended questions were included for gathering detailed information. The questionnairre was based mainly on a previous study by Schlegelmilch \& Houston (1989); although aspects of implementation other than codes of conduct were also considered. The completed questionnaire was pilot tested with two companies in the Midlands and was found to be satisfactory.

\section{Sample}

The Times 1000 companies was used as the sampling frame. Due to time and financial constraints a random generator was used to select 300 companies from that list. The questionnaire was posted to these companies in November 1992. By the cut-off date 92 responses were received representing a $31 \%$ response rate. Of these 16 were not filled in. Reasons stated were: 'it's company policy not to complete questionnaires'; 'we receive too many requests so we have decided not to participate in any'; 'we do not have the time to complete the questionnaire'. This left 76 usable replies, representing a 25\% response rate. A comparison of 38 'early' returns with the 38 'late' returns yielded no statistically significant differences in terms of questionnaire responses $(p<.05)$ thus suggesting a lack of non-response bias (Armstrong \& Overton, 1977). A profile of the respondents is shown in Table 1.

Forty-five respondents were listed on the London Stock Exchange and 31 were not. Of the non-listed companies, seven were in the service sector and 24 in the industrial sector. The listed companies were spread widely amongst most of the sectors on the stock exchange. Altogether $80 \%$ of the sample had been in business for longer than 25 years. While the response rate was relatively high for a mail survey, the results may not be generalizable over all British companies, but rather representative of large highly visible companies, because the sampling frame used tended to be these types of organisations.

\section{Limitations}

This survey was subject to two limitations. Firstly, although the questionnaire was addressed to the chief executive officer of the companies, its completion may have been delegated to
Table 1 Profile of respondents

\begin{tabular}{|c|c|c|}
\hline Non-listed companies - type of business $n=31$ & No. & \% \\
\hline Sarvice & 7 & 23 \\
\hline Industrial & 24 & 77 \\
\hline \multicolumn{3}{|l|}{ Listed companies - sectars represented $n=45$} \\
\hline Banks & 2 & 4 \\
\hline Brewers and distilkers & 2 & 4 \\
\hline Building muerials & 4 & 9 \\
\hline Business services & 1 & 2 \\
\hline Chemicals & 2 & 4 \\
\hline Conglomerates & 1 & 2 \\
\hline Contracting and construction & 1 & 2 \\
\hline Elearicals & 2 & 4 \\
\hline Elearonics & 1 & 2 \\
\hline Engineering - eerospece & 1 & 2 \\
\hline Engineering - general & 4 & 9 \\
\hline Food manufacturing & 3 & 7 \\
\hline Health and household & 1 & 2 \\
\hline Hoteis and leisure & $\mathbf{1}$ & 2 \\
\hline Insurance composite & 1 & 2 \\
\hline Invesiment trusts & 1 & 2 \\
\hline Media & 1 & 2 \\
\hline Metals and mad forming & 2 & 4 \\
\hline Miscellaneous & 1 & 2 \\
\hline Oil and gas & 2 & 4 \\
\hline Packaging, paper and printing & 2 & 4 \\
\hline Property & 2 & 4 \\
\hline Stores & 3 & 7 \\
\hline Transport & 1 & 2 \\
\hline Water & 2 & 4 \\
\hline Mines & 1 & 2 \\
\hline
\end{tabular}

another officer of the company. The views of these respondents may differ from those of chief executives. Secondly, socially desirable answers may have been given, which is always a possibility in surveys of this nature.

\section{Results of survey}

Of the 76 respondents, $54 \%$ said that they do go out of their way to promote ethical awareness. These companies all have a code of ethics. Their approaches to deliberately fostering ethical decision making are shown in Table 2.

The most important ways organisations in the sample attempt to deliberately and explicitly foster ethical decision making are the establishment and/or review of policies for ethical issues, and attempts to recruit employees with strong moral character. Employee training in ethics, through the use of seminars and videos is also used, as well as ethics discussions at meetings. Ethics committees are not used very often despite being proposed by Gandz \& Bird (1989). The results from Table 2 do support Schlegelmilch \& Houston's (1989) view that a formal code of ethics does not stand in isolation but is associated with greater attention to ethical issues in general. Although companies are selling the scene for ethical 
Table 2 Approaches to deliberately fostering ethical decision making

\begin{tabular}{lcc}
\hline Approaches & $\mathrm{n}=$ & 41 \\
& No. & $\%$ \\
\hline Establishment and/or review of policies for ethical issues & 26 & 79 \\
Attempts to recruit employees with strong moral character & 23 & 70 \\
Employee training in ethics (e.g. videos and seminars) & 12 & 36 \\
Ethics discussions and meetings & 9 & 27 \\
Ethics committee & 6 & 18 \\
Social audits and reports & 5 & 15 \\
Company policy & 2 & 6 \\
Complying with statutory rules & 2 & 6 \\
Implementation of a reward system for ethical behaviour & 1 & 3 \\
Ethics 'hotline' reporting & 1 & 3 \\
\hline Note: Multiple responses & & \\
\hline
\end{tabular}

behaviour, few are actively engaged in enforcing and controlling it.

Forty-one companies ( $54 \%$ ) did have a formal written code of ethics. This finding is very similar to a survey conducted by the Institute of British Ethics who found that $55 \%$ of the largest British companies had a code of ethics (Webley, 1989), although higher than the Schlegelmilch \& Houston British survey. The finding reinforces the view that British companies are lagging behind their American counterparts.

The most popular name of the company's code was 'Code of Ethics', 'Code of Conduct' and 'Code of Business Practice'.

As far as the date of introduction of a code, $85 \%$ of the respondents introduced their code since 1980 and $47 \%$ since 1989. Codes have therefore been a relatively new phenomenon which is growing in popularity. The reasons for developing a code are presented in Table 3 .

The most popular reasons for developing a code were to stress good corporate citizenship, to protect against misconduct and to ensure that the company abides by established laws. Only $17 \%$ said external pressure played a role. Starr (1983) warns that a danger exists when the codes are used as a public relations gimmick. However, the results show that

Table 3 Reasons for developing a code

\begin{tabular}{lcc}
\hline Reasons & $\mathrm{n}=$ & 41 \\
& No. & $\%$ \\
\hline External pressure (e.g. auditors, governor) & 7 & 17 \\
In order to stress good corporate citizenship & 27 & 66 \\
To protect against misconduct & 22 & 54 \\
Due to a change in corporate structure & 7 & 17 \\
In order to ensure that the company abides by established laws & 20 & 49 \\
For a public relations activity & 3 & 7 \\
To promote high standards across countries & 3 & 7 \\
Outlook of the founding managers & 1 & 2 \\
To clarify business objectives & 1 & 2 \\
\hline Note: Multiple responses & & \\
\hline
\end{tabular}

only $7 \%$ of the respondents use the code for this type of activ. ity.

The body and/or persons responsible for the development of the code of ethics is shown in Table 4.

The most important person/s responsible for the development of the code was the Chairman/Chief Executive Officer, the board of directors, and senior management. This finding supports Murphy (1988) who notes that the role of top management is instrumental in making the ethical programme work.

The distribution of the code of ethics is presented in Table 5.

Schlegelmilch \& Houston (1989) illustrate that the wide circulation of a code of ethics, particularly to those external to the company, is very important because the company publicly commits itself to its social responsibilities and might therefore become a target for criticism.

The results show that all managers receive the code as well as most of the other employees. Very few outsiders receive copies of the code. Only $22 \%$ of shareholders, $15 \%$ of customers and 5\% of suppliers. This is surprising and indicates once more that whilst British companies may be planning for ethical conduct they are failing to implement their plans satisfactorily.

Table 4 Body/persons responsible for the development of code of ethics

\begin{tabular}{lcc}
\hline & No. & $\%$ \\
\hline Corporate Head Office & 3 & 7 \\
Chairman/CEO & 10 & 24 \\
Board of Directors & 7 & 17 \\
Corporate Affairs Director & 3 & 7 \\
Head of Corporate Communications & 1 & 2 \\
Director of Personnel & 1 & 2 \\
Senior Management & 7 & 17 \\
Company/Legal Department & 1 & 2 \\
Legal and Personnel Staff & 1 & 2 \\
H.R. and Hire Manager & 5 & 12 \\
Code of Conduct Committee & 1 & 2 \\
Compliance Officer & 1 & 2 \\
\hline Note: Multiple responses & & \\
\hline
\end{tabular}

Table 5 Distribution of code

\begin{tabular}{lcc}
\hline Recipients & $\mathrm{n}=$ & 41 \\
& No. & $\%$ \\
\hline Shareholders & 9 & 22 \\
Public Relations Officers & 4 & 10 \\
Customers & 6 & 15 \\
Managers & 41 & 100 \\
Employees & 31 & 76 \\
Suppliers & 2 & 5 \\
Anyone who enquires & 2 & 5 \\
\hline Note: Multiple responses & &
\end{tabular}

Note: Multiple responses 
The effect that the code of ethics had on the company elicited differing responses. Although $37 \%$ of respondents felt that their code had a positive effect, $17 \%$ said it was very difficult to judge and another $12 \%$ said it was too early to say. Another $12 \%$ said they did not know as it is difficult to measure.

Of the 35 respondents $(46 \%)$ that did not have a code of ethics, ten (29\%) state that there are other documents in their company which addresses the issue of ethical behaviour. These included mission statements, staff handbooks, human resource policies and procedures and the contract of employment.

On the likelihood of establishing a code within the next three years, $51 \%$ of the respondents say it is unlikely, $43 \%$ are unsure and only $6 \%$ say it was likely. The main reason for these findings is that these organisations abide by other codes - specifically industry and professional codes of practice.

\section{Conclusion}

The results show that British companies still have a long way to go and need more commitment in implementing ethical programs. Only $54 \%$ go out of their way to foster ethical decision making and had a formal code of ethics. This compares unfavourably with American and Canadian organisations. There are indications however that there is a growing ethical awareness and concern amongst British companies and the growth of formal codes has increased in recent years, despite the fact that they are concerned with economic survival in recessionary conditions.

Of the respondents that do have a code of ethics, the senior management have been instrumental in implementing them. These codes are distributed internally and to a far lesser degree externally. This should be rectified as informed customers and suppliers can act as regulators of misconduct if policies become known.

It is clear that the enforcement of ethical behaviour will depend on two things. Firstly, certain actions are easy to enforce and others are not. For example, safety is easier to enforce than caring for customers. Secondly, the nature of the firm, the type of industry it is in, its strategy and structure all influence ethical behaviour. The enforcement of ethics in a highly competitive environment may be more difficult than in stable monopolistic environments. Overall, large British organisations appear to be making genuine attempts to foster ethical behaviour in their companies. The reality of business life means that ethics and codes are sometimes abstracted away from their intelligible meaning to the organisation. Thus, implementation, control and measurement issues, still need both academic and practitioner attention.

\section{References}

Andrews, K.R., 1989. 'Ethics in practice', Harvard Business Review, Vol. 67: 99-104.

Armstrong, S.J. \& Overton T.S. 1977. 'Estimating non-response bias in mail surveys', Journal of Marketing Research. Vol. 14: 396402.

Arrow, K.J., 1973. 'Social responsibility and economic efficiency', Public Policy, Vol. 21 : 303-317.

Becker, H. \& Frizsche, L, 1987. 'Business ethics: a cross cultural comparison of managers' attitudes', Journal of Business Ethics, Vol. 6: 289-295.
Benson, G.C.S. 1989. 'Codes of ethics', Journal of Business Ethics, Vol. 8: 305-319.

Brenner, S.N. 1992. 'Ethics programmes and their dimensions', Journal of Business ethics, Vol. 11: 391-399.

Brenner, S.N. \& Molander, E.A. 1977. 'Is the ethics of business changing?', Harvard Business Review, Vol. 55: 57-71.

Brooks, L.J. 1989. 'Corporate codes of ethics', Journal of Business ethics, Vol. 8: 305-319.

Buller, P.F., Kohls, J.J. \& Anderson, K.S. 1991. 'The challenge of global ethics', Journal of Business Ethics, Vol. 10: 767-775.

Byron, S.J. \& Williams J. 1977. 'The meaning of ethics in business', Business Horizons, Vol. 20: 75-80.

Centre for Business Ethics, 1986. 'Are Corporations Institutionalising Ethics?', Journal of Business Ethics, Vol. 5: 85-91.

Chatov, R. 1980. 'Danger signs of unethical behaviour : how to determine if your firm is at ethical risk', Journal of Business Ethics, Vol. 10: 249- 253.

Cressey, D.A. \& Moore, C.A. 1983. 'Managerial values and corporate codes of ethics', California Management Review, Vol. 25: 53-77.

Davis, J.R. \& Walton, R.E, 1991. 'Professional ethics: business students' perceptions', Journal of Business Ethics, Vol. 10: 451464.

Delaney, J.T. \& Stockwell, D. 1992. 'Do company ethics training programmes make a difference. An empirical analysis', Journal of Ethics, Vol. 11: 719-727.

Donaldson, A. 1989. Key issues in business ethics. San Diego: Academic Press.

Enderle, G., 1987. 'Some perspectives of managerial ethical leadership', Journal of Business Ethics, Vol. 11: 657-663.

Epstein, E.M. 1979. Societal, managerial and legal perspectives on corporate social responsibility product process', The Hastings Law Journal, Vol. 30.

Finlay, J.R. 1989. 'Survival ethics', Business Quarterly, Vol. 40: 44. Gandz, J. \& Bird, F.G. 1989. 'Designing ethical organisations', Business Quarterly, Vol. 54: 108-112.

Knouse, S.B. \& Giacalone, R.A., 1992. 'Ethical decision making in business behavioural issues and concerns', Journal of Business Ethics, Vol. 11: 369-377.

Laczniak, G.R. \& Inderrieden, E.J. 1987. 'The influence of stated organisational concerns upon ethical decision planning', Journal of Business Ethics, Vol. 6: 297-307.

Lefebvra, M. \& Singh, J.B. 1992. 'The content and focus of Canadian corporate codes of ethics', Journal of Business Ethics, Vol. 11: 799-808.

Leory, X. \& Caldwell, D., 1992. 'Corporate ethics. Tomorrow's decision makers speak out', Fortune International, July 27 th, No. 15.

Melrose-Woodman, J. \& Kverndal, I. 1976. 'Towards social responsibility: company codes of ethics and practice', British Institute of Management Survey Report, No. 28.

Molander, E.A. 1987. 'A paradigm for design promulgation and enforcement of ethical codes', Journal of Business Ethics, Vol. 6: 619-631.

Murphy, P.E. 1988. 'Implementing business ethics', Journal of Business Ethics, Vol. 7: 907-915

Murphy, P.E., Smith, J.E. \& Daley, J.M., 1992. 'Executive attitudes, organisational size and ethical issues: perspectives and service 
industry', Journal of Business Ethics, Vol. 11: 11-19.

Oliverio, M.E. 1989. 'The implementation of a code of ethics : the carly effects of one entrepreneur', Journal of Business Ethics, Vol. 8: $367-374$

Purcell, T.V. 1977. 'Do courses in business ethics pay off?', California Management Review, Vol. 19: 50-58.

Raiborn, C.A. \& Payne, D. 1990. 'Corporate codes of conduct: a collective conscience and continum', Journal of Business Ethics, Vol 10: 879-889.

Schlegelmilch, B. \& Houston, J.E. 1989. 'Corporate codes of ethics in large U.K. companies. An empirical investigation of use, content and attitudes' , European Journal of Marketing, Vol. 23, No. 6: 7-24.

Sims, R., 1991. 'The institutionalization of organisational ethics',
Journal of Business Ethics, Vol. 10: 493-506.

Starr, W. 1983. 'Codes of ethics - towards a rule utilitarian justification', Journal of Business Ethics, Vol. 2: 99-106.

The Times 1000. 1991-1992. 1992. London: Times Books.

Tsalikis, J. \& Fritzsche, D.J., 1989. 'Business ethics. A literature review with a focus on marketing ethics', Journal of Business Ethics, Vol. 8: 695- 743.

Webley, S. 1989. Company philosophies and codes of business ethics, The Institute of Business Ethics, London.

Weeks, W. \& Nantel, J. 1992. 'Corporate codes of ethics and sales force behaviour: a case study', Journal of Business Ethics, Vol. 11: 753-760.

Weller, S. 1988. 'The effectiveness of corporate codes of ethics', Journal of Business Ethics, Vol. 7: 389-395. 